\title{
TINJAUAN TEKNOLOGI PENGOLAHAN LEACHATE DI TEMPAT PEMBUANGAN AKHIR (TPA) SAMPAH PERKOTAAN
}

\author{
Oleh : \\ Wahyu Purwanta \\ Pusat Teknologi Lingkungan, Badan Pengkajian dan Penerapan Teknolgi (BPPT)
}

\begin{abstract}
Leachate is defined as a liquid, which flows through waste and extracts suspended material or their suspension. In most landfill, leachate is consist of liquids that go into the landfill, which originated from outside the landfill, such as surface drainage, rain water, ground water, water from spring water and other liquids which produced from waste decomposition. The existence of pollutant material or minerals in water body that is originated from leachate will propose the growth of microorganisms, which are harmful for human health and reduce the aesthetic.

Leachate handling could be done with several methods, such as: utilization of hydrolic characteristics by ground water adjustment, thus the leachate flows would not go into the direction of ground water. Another way of leachate handling are: landfill isolation, in order to prevent the inflow of external water and the outflow of leachate water; site selection of an area, which has a good capability of pollutant neutralization; leachate recirculation to be redirected to the solid waste pile; flowing the leachate to domestic waste treatment system and leachate processing with a certain system.

Some processing techniques that are often to be used are: physical-chemical processing, such as coagulation-flocculation-settling; aerobic processing (activated sludge, stabilization pond or aeration pond); anaerobic processing, such as stabilization pond and utilization of sorption characteristics, such as active carbon. The aerobic stabilization pond system is suitable for Indonesian condition due to the availability of sunlight, simple, relatively cheap and their capability of BOD reduction above of $90 \%$ and COD reduction of above $80 \%$.
\end{abstract}

Kata Kunci : Leachate, TPA sampah, teknologi pengolahan.

\section{PENDAHULUAN}

Sampah padat di TPA tidak hanya tersusun oleh komponen padatan, tetapi juga mengandung cairan sampah yang didalamnya terkandung zat-zat kimia, baik organik maupun anorganik serta sejumlah bakteri pathogen, yang disebut sebagai leachate, (Damanhuri 1993).

Leachate didefinisikan sebagai cairan yang menapis melalui limbah dan mengekstrak material terlarut atau tersuspensinya. $\mathrm{Di}$ kebanyakan TPA, leachate terdiri atas cairan yang masuk TPA dari sumber-sumber luar, seperti drainase permukaan, air hujan, air tanah, dan air dari mata air serta cairan yang diproduksi dari dekomposisi limbah. Dalam definisi lain, leachete adalah sebagai limbah cair yang terbentuk akibat masuknya air eksternal kedalam timbunan sampah, melarutkan dan membilas materi-materi terlarut termasuk senyawa organik dan anorganik hasil proses dekomposisi (Tchobanoglous, 1993).

Leachate tersebut merupakan cairan yang terbentuk oleh adanya air hujan yang merembes kedalam timbunan sampah, serta adanya kandungan air tanah yang tinggi. Aliran yang merembes ini akan menimbulkan aliran yang membawa bermacam-macam zat yang ada dalam sampah seperti Nitrat, Nitrit, Metan, Karbon dioksida $\left(\mathrm{CO}_{2}\right)$, Sulfat, Sulfida, $\mathrm{NH}_{3}$, air dan mikroorganisme (Damanhuri, 1993).

Proses dekomposisi secara alamiah pada awalnya menghasilkan nitrit, $\mathrm{CO}_{2}$ dan air, sedangkan pasokan (supply) oksigen yang dilepaskan oleh mikroorganisme anaerobik akan membentuk senyawa lain seperti Sulfat, Amoniak dan Nitrogen. Kualitas dan kuantitas leachete sangat bervariasi dan fluktuasinya secara langsung berkaitan dengan banyaknya curah hujan, komposisi / karakteristik sampah, umur timbunan dan pola operasional di TPA.

Pengaruh leachate yang dirasakan masyarakat adalah adanya perubahan warna atau kekeruhan pada badan air ataupun keberadaan leachate yang mengandung zat organik dan bahan terlarut lainnya. Selanjutnya dengan adanya air hujan akan masuk ke badan air dan air tanah yang akhirnya akan menjadi keruh. Adanya bahan pencemar atau mineral di badan air akan memacu pertumbuhan dan perkembangbiakan mikroorganisme yang merugikan kesehatan dan estetika. 


\section{LAJU TIMBULAN LEACHATE}

Leachate adalah limbah cair yang timbul akibat masuknya air eksternal ke dalam timbunan sampah, melarutkan dan membilas materi-materi terlarut atau merupakan hasil proses dekomposisi sampah berbentuk cair yang berwarna coklat kehijauan dan merupakan pencemar potensial ke lingkungan apabila TPA tidak dikelola secara memadai. Dari sana dapat diramalkan bahwa kuantitas dan kualitas leachate akan sangat bervariasi dan berfluktuasi. Timbulan leachate (lechate generation) dipengaruhi oleh curah hujan (presipitasi harian), aliran permukaan, infiltrasi, evaporasi, transpirasi, temperatur, komposisi sampah, kelembaban dan kedalaman/ketinggian tumpukan sampah di TPA (Leckie, 1979). Secara umum timbulan leachate dapat dihitung berdasarkan persamaan berikut (Qasim, 1994);

$$
\begin{aligned}
& \mathrm{PERC}=\mathrm{P}-(\mathrm{R} / \mathrm{O})-(\mathrm{AET})-(\Delta \mathrm{ST}) \\
& \text { dimana, } \\
& \mathrm{PERC}=\text { perkolasi } \\
& \mathrm{P}=\text { presipitasi (curah hujan) } \\
& \mathrm{R} / \mathrm{O}=\text { surface run off } \\
& \mathrm{AET}=\text { evapotranspirasi aktual } \\
& \Delta \mathrm{ST}=\text { perubahan kelembaban tanah }
\end{aligned}
$$

\section{KOMPOSISI \& KARAKTERISTIK}

Secara umum komponen (unsur-unsur) kimia dan bakteri yang terkandung dalam leachate dapat dilihat dalam tabel 1 berikut :

Tabel 1. Komposisi Penyusun Leachate

\begin{tabular}{|c|l|c|c|}
\hline \multirow{2}{*}{ No. } & \multirow{2}{*}{ KOMPONEN } & \multicolumn{2}{|c|}{ KADAR (ppm) } \\
\cline { 3 - 4 } & & RENDAH & TINGGI \\
\hline 1. & $\mathrm{pH}$ & 6,0 & 6,5 \\
\hline 2. & $\begin{array}{l}\text { Kesadahan } \\
\mathrm{CaCO}_{3}\end{array}$ & 890 & 7600 \\
\hline 3. & $\begin{array}{l}\text { Alkalinitas } \\
\mathrm{CaCO}_{3}\end{array}$ & 730 & 9500 \\
\hline 4. & $\mathrm{Ca}$ & 240 & 2330 \\
\hline 5. & $\mathrm{Mg}$ & 64 & 410 \\
\hline 6. & $\mathrm{Na}$ & 85 & 1700 \\
\hline 7. & Fe total & 8,7 & 220 \\
\hline 8. & Besi ferro & 6,5 & 87 \\
\hline 9. & Klorida & 96 & 2350 \\
\hline 10. & Sulfat & 84 & 730 \\
\hline 11. & Phosphate & 0,3 & 29 \\
\hline 12. & Organik $\mathrm{N}$ & 2,4 & 465 \\
\hline 13. & NH ${ }_{4}-\mathrm{N}$ & 0,22 & 480 \\
\hline 14. & BOD & 2170 & 3030 \\
\hline
\end{tabular}

Sumber : Qasim (1994)
Kualitas leachate menurut Qasim (1994) dipengaruhi oleh komposisi sampah, ketebalan timbulan sampah, laju air, cara operasional TPA (aerobik, semi aerobik, anaerobik), umur TPA dan interaksi leachate dengan TPA. Sementara dari Damanhuri (1995) selain faktor di atas juga ditambahkan faktor kondisi saat sampling. Tabel 2 memperlihatkan karakteristik leachate dari TPA di luar negeri (Chian \& De Walle, 1976) serta Tabel 3 memperlihatkan kualitas leachate di beberapa TPA di Indonesia dan China.

Dari kedua tabel tersebut terlihat bahwa leachate mempunyai karakteristik yang khas yaitu;

> Leachate dari TPA yang muda bersifat asam, berkandungan organik yang tinggi, mempunyai ion-ion terlarut yang juga tinggi serta rasio $\mathrm{BOD} / \mathrm{COD}$ relatif tinggi.

> Leachate dari TPA yang sudah tua sudah mendekati netral, mempunyai kandungan karbon organik dan mineral yang relatif menurun serta rasio $\mathrm{BOD} / \mathrm{COD}$ relatif menurun.

Dengan membandingkan kualitas leachate dari TPA di China dan hasil pemantauan leachate di beberapa TPA telah dilakukan di Indonesia sejak tahun 1988 (Damanhuri 1995) dapat disampaikan bahwa :

$>$ Leachate dari TPA di Indonesia mempunyai karakter tidak asam dibanding dengan TPA yang ada di China.

$>$ Meskipun nilai COD TPA di Indonesia lebih rendah dibanding nilai COD TPA yang ada di China, namun sesuai dengan Kep03/MENKLH/II/91 COD yang terkandung melebihi baku mutu efluen limbah cair yang ditentukan sehingga penanganan leachate merupakan suatu keharusan sebelum dilepas ke lingkungan.

\section{TEKNOLOGI PENANGANAN LEACHATE}

Dari data Yang tertera pada Tabel 2 dan Tabel 3 tersebut di atas belumlah dapat diandalkan untuk menentukan besaran beban organik yang dibutuhkan dalam perancangan suatu pengolah limbah di Indonesia. Dibutuhkan suatu pemantauan yang lebih bervariasi lagi dari TPA lain yang terletak dalam geografi yang lebih luas, termasuk leachate dari TPA yang terletak di daerah rawa dan sebagainya.

Penanganan leachate yang sudah dapat dilakukan dengan berbagai cara, antara lain;

Memanfaatkan sifat-sifat hidrolis dengan pengaturan air tanah sehingga aliran leachate tidak menuju kearah air tanah 
Tabel 2. Kualitas leachate sesuai dengan umur TPA

\begin{tabular}{|l|c|c|c|}
\hline \multirow{2}{*}{ Parameter } & \multicolumn{3}{c|}{ Umur TPA } \\
\cline { 2 - 4 } & 1 tahun & 5 tahun & 16 tahun \\
\hline BOD & $7500-28000$ & 4000 & 80 \\
\hline $\mathrm{COD}$ & $10000-40000$ & 8000 & 400 \\
\hline $\mathrm{pH}$ & $5,2-6,4$ & 6,3 & - \\
\hline TDS & $100-79$ & - & - \\
\hline $\mathrm{DHL}$ & $600-9000$ & - & - \\
\hline Alkalinitas $\left(\mathrm{CaCO}_{3}\right)$ & $800-4000$ & 5810 & 2250 \\
\hline Hardness $\left(\mathrm{CaCO}_{3}\right)$ & $3500-5000$ & 2200 & 540 \\
\hline Total P & $25-35$ & 12 & 8 \\
\hline Ortho P & $23-33$ & - & - \\
\hline NH4-N & $56-482$ & - & - \\
\hline Nitrat & $0,2-0,8$ & 0,5 & 1,6 \\
\hline Kalsium & $900-11700$ & 308 & 109 \\
\hline Khlorida & $600-800$ & 1330 & 70 \\
\hline Sodium & $450-500$ & 810 & 34 \\
\hline Potasium & $295-310$ & 610 & 39 \\
\hline Sulfat & $400-650$ & 2 & 2 \\
\hline Mangan & $75-125$ & 0,06 & 0,06 \\
\hline Magnesium & $160-250$ & 450 & 90 \\
\hline Besi & $210-325$ & 6,3 & 0,6 \\
\hline Seng & $10-30$ & 0,4 & 0,1 \\
\hline Tembaga & - & $<0,5$ & $<0,5$ \\
\hline Kadmium & - & $<0,05$ & $<0,05$ \\
\hline Timbal & - & 0,5 & 1,0 \\
\hline Sumber & & & \\
\hline
\end{tabular}

Sumber : Chian \& De Walle (1976)

Tabel 3. Gambaran variasi kualitas leachate dari beberapa TPA

\begin{tabular}{|lccccc|}
\hline Kota/TPA & pH & COD & N-NH4 & N-NO2 & DHL \\
\hline Bogor & 7,5 & 28723 & 770 & 0 & 40480 \\
& 8 & 4303 & 649 & 0,075 & 24085 \\
\hline Cirebon & 7 & 3648 & 395 & 0,225 & 10293 \\
& 7 & 13575 & 203 & 0,375 & 12480 \\
\hline Jakarta & 7,5 & 6839 & 799 & 0 & 13680 \\
& 7 & 413 & 240 & 0,075 & 3823 \\
& 8 & 1109 & 621 & 0,35 & 1073 \\
\hline Bandung & 6 & 58661 & 1356 & 6,1 & 26918 \\
(Leuwigajah) & 7 & 7379 & 738 & 2,775 & 20070 \\
\hline Yogyakarta & 6 & 6166 & 162 & 0,225 & 3540 \\
\hline Surabaya & 8,03 & 24770 & 155 & 0,077 & 6030 \\
\hline China & & & & & \\
Umur 1 th & $5,2-6,4$ & $10000-40000$ & $56-482$ & - & $600-9000$ \\
Umur 5 th & 6,3 & 8000 & - & - & - \\
Umur 16 th & - & 400 & - & - & - \\
\hline
\end{tabular}

Sumber : Diolah dari berbagai sumber. 
$>$ Mengisolasi TPA tersebut agar air eksternal tidak masuk dan leachate-nya tidak keluar

$>$ Mencari lahan yang mempunyai tanah dasar dengan kemampuan baik untuk menetralisir cemaran.

> Mengembalikan leachate (resirkulasi) ke arah timbunan sampah.

$>$ Mengalirkan leachate menuju pengolah air domestik.

$>$ Mengolah leachate dengan pengolahan tersendiri.

Di negara maju biasanya masalah leachate ini ditangani dengan diolah seperti halnya air limbah biasa. Beberapa jenis pengolahan yang biasa digunakan;

$>$ Pengolahan fisik-kimiawi biasanya koagulasi-flokulasi-pengendapan.

$>$ Pengolahan secara aerobik ; lumpur aktif, kolam stabilisasi atau kolam aerasi.

$>$ Pengolahan secara anaerobik, biasanya kolam stabilisasi.

$>$ Pemanfaatan sifat-sifat sorpsi seperti karbon aktif.

\subsection{Pengendapan dengan kapur}

Salah satu cara dalam pengolahan leachate adalah dengan mengendapkan melalui proses sedimentasi dengan bantuan presipitasi kapur (lime). Kapur dalam jumlah yang mencukupi harus ditambahkan dengan asam karbonik bebas dan dengan asam karbonik dari bikarbonat guna menghasilkan kalsium karbonat yang bertindak sebagai koagulan.

$>$ Efeknya mulai terlihat $\mathrm{pH}=7$ dengan dosis $1-6 \mathrm{mg} / \mathrm{l}$

$>$ Salah satu hasil yang didapat;

Penyisihan COD = 61 \% dari $18.550 \mathrm{mg} / \mathrm{L}$

Penyisihan BOD $=51,7 \%$ dari 10.910

$\mathrm{mg} / \mathrm{L}$

Penyisihan $\mathrm{Fe}=98,8 \%$ dari $312 \mathrm{mg} / \mathrm{L}$

Penyisihan $\mathrm{Zn}=97,1 \%$ dari $21 \mathrm{mg} / \mathrm{L}$

Penyisihan $\mathrm{Hg}=57,1 \%$ dari $0,007 \mathrm{mg} / \mathrm{L}$

\subsection{Koagulasi-flokulasi}

Sama dengan prinsip sedimentasi dengan pembubuhan kapur, pada prinsip ini hanya koagulan yang digunakan bisa alumunium sulfat [ $\mathrm{Al}\left(\mathrm{SO}_{4}\right)$ ] dan ferri khloride [ $\mathrm{Fe} \mathrm{Cl}_{3}$ ]. Hasil dari uji tersebut antara lain;

$>$ Koagulan alumunium sulfat.

Dosis $100 \mathrm{mg} / \mathrm{L}$ menyisihkan COD < 10\%

dan Fe sampai $60 \%$

Dosis $1000 \mathrm{mg} / \mathrm{L}$ menyisihkan COD $<10 \%$

dan Fe sampai $96 \%$

$>$ Koagulan ferri khloride.

Dosis $100 \mathrm{mg} / \mathrm{L}$ menyisihkan COD sampai $12 \%$ dan Fe sampai $21 \%$ dosis $1000 \mathrm{mg} / \mathrm{L}$ menyisihkan COD sampai 16,3\% dan Fe sampai 95\%

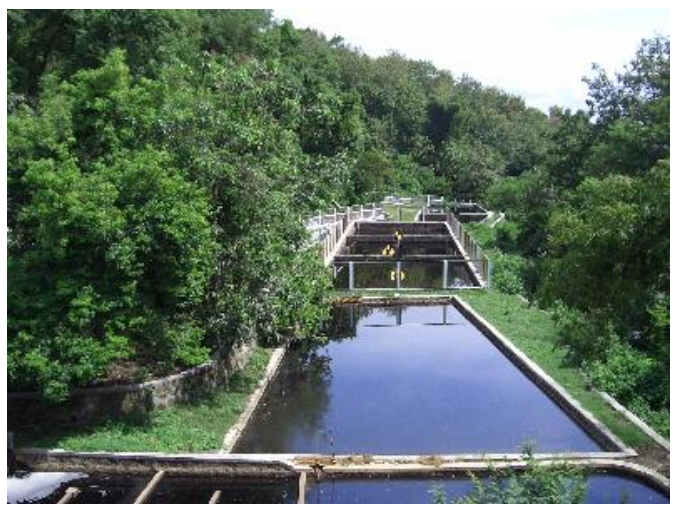

Gambar 1 : Unit pengolah leachate di TPA Piyungan Yogyakarta berupa aerated lagon.

\subsection{Proses lumpur aktif}

Selain pengolahan secara fisik-kimiawi seperti diatas, leachate juga dapat diolah dengan mengkombinasikan dengan proses biologis memanfaatkan mikroorganisme seperti dalam activated sludge (lumpur aktif). Cara ini banyak diterapkan di lapangan, dan sangat efektif terutama bila diawali dengan pengendapan mineral (logam berat) dengan pembubuhan kapur; salah satu hasilnya adalah penyisihan;

$$
\begin{aligned}
\mathrm{BOD} & =99,1 \% \text { dari } 12.000 \mathrm{mg} / \mathrm{L} \\
\mathrm{COD} & =94,9 \% \text { dari } 18.000 \mathrm{mg} / \mathrm{L} \\
\mathrm{Cd} & =87,5 \% \text { dari } 0,08 \mathrm{mg} / \mathrm{L} \\
\mathrm{Cr} & =75 \% \text { dari } 0,28 \mathrm{mg} / \mathrm{L} \\
\mathrm{Fe} & =99,2 \% \text { dari } 376 \mathrm{mg} / \mathrm{L} \\
\mathrm{Ni} & =60,2 \% \text { dari } 1,91 \mathrm{mg} / \mathrm{L} \\
\mathrm{Pb} & =85,4 \% \text { dari } 0,82 \mathrm{mg} / \mathrm{L} \\
\mathrm{Zn} & =97,4 \% \text { dari } 22 \mathrm{mg} / \mathrm{L} \\
\mathrm{Hg} & =28,9 \% \text { dari } 0,006 \mathrm{mg} / \mathrm{L}
\end{aligned}
$$

\subsection{Kolam Stabilisasi Aerobik}

Kolam stabilisasi aerobik (aerobic stabilization ponds) adalah proses pengolahan limbah cair secara alami dalam wujud kolam yang lebar dengan melibatkan algae dan bakteri dan dalam kondisi aerobik hingga kedalaman kolamnya. Ada dua tipe utama, tipe pertama bertujuan memaksimumkan produksi algae, pada jenis ini kolam dibatasi dengan kedalaman $150 \mathrm{~cm}-450 \mathrm{~cm}$. Pada tipe kedua, ditujukan untuk produksi oksigen sebanyak-banyaknya, dan kedalaman kolam hingga 1,5 meter.

Agaknya sistem ini cocok untuk kondisi Indonesia karena relatif tersedia sinar matahari, sederhana dan relatif murah. Beberapa hasil dari negara yang memiliki musim dingin adalah; 
- TPA Lingen (Jerman), dengan waktu kontak 100 hari diperolah penyisihan BOD sebesar $99,8 \%$

- $\quad$ TPA Ugley (Inggris), waktu kontak 100 hari diperoleh penyisihan BOD 99,7\% dan COD $97,1 \%$

- TPA Peslan (Perancis), total penyisihan BOD (diakhiri dengan pembubuhan kapur) adalah $96 \%$ dan COD sebesar $80 \%$

\subsection{Kolam Stabilisasi Anaerobik}

Secara teori, kolam anaerobik digunakan untuk pengolahan limbah kandungan organik tinggi yang juga sangat tinggi konsentrasi padatannya. Waktu kontak 15 hari dengan beban $1-2 \mathrm{~kg} \mathrm{COD} / \mathrm{m} 3 /$ hari diperoleh penyisihan COD antara $85-90 \%$ dari COD masuk rata-rata $27.000 \mathrm{mg} / \mathrm{L}$ (TPA San Liberale - Italy).

Pada penelitian skala laboratorium terhadap kemungkinan terolahanya leachate antara lain menghasilkan :

- Aerasi leachate selama $10-14$ hari dapat menurunkan COD sampai $85 \%$, kombinasi dengan dilanjutkan karbon aktif menghasilkan penurunan COD hingga $90 \%$.

- Timbunan sampah yang sudah menjadi kompos ternyata juga mampu menurunkan pencemar organik, pada simulasi dengan umpan COD $2500 \mathrm{mg} / \mathrm{l}$ dan dioperasikan secara anaerobik menghasilkan penyisihan COD $80 \%$.

Cara resirkulasi leachate sudah banyak diterapkan dalam pengelolaan leachate. Ada dua keuntungan dari cara ini, yaitu;

- Mempercepat proses evaporasi.

- Mereduksi cemaran organik leachate.

\section{SISTEM PENGELOLAAN}

Pengelolaan leachate merupakan bagian dari pengelolaan TPA secara keseluruhan. Pada dasarnya keberhasilan penanganan leachate dimulai sejak suatu lahan dipilih, dan terus menerus sampai lahan itu ditutup karena penuh. Oleh karenanya usaha penanganan masalah leachate dapat dikelompokkan dalam beberapa tahap, yaitu:

- Tahap pemilihan lokasi.

- Tahap perancangan dan penyiapan site.

- Tahap lama masa pengoperasian.

- Tahap elama jangka waktu tertentu setelah TPA tidak digunakan lagi.

Di Indonesia saat ini telah mempunyai standar tentang cara pemilihan lokasi sebuah TPA sampah kota, yaitu SNI No. 03-3241-1994 tentang Tata Cara Pemilihan Lokasi TPA. Aspek pencegahan pencemaran leachate dalam standar ini mendapatkan porsi yang baik, melalui pertimbangan bahwa;

- Lahan sebuah TPA biasanya terletak di luar kota yang kadangkala berdekatan dengan perumahan penduduk yang belum terjangkau oleh sistem PDAM yang baik, sehingga masalah pencemaran leachate perlu dipertimbangkan.

- Hujan di Indonesia yang cukup tinggi.

Pengelolaan leachate pada dasarnya sangat tergantung kepada karakteristiknya, sedangkan karakteristik leachate juga sangat tergantung bagaimana leachate tersebut terbentuk/ terakumulasi. Secara ideal suatu pengolahan leachate harus dilakukan uji keterolahan terlebih dahulu (treatability) dan dibuat juga skala pilotnya.

Langkah awal dalam pengelolaan leachate adalah memperhatikan sistem lapisan bawah TPA (liners system). Tujuan dari disain sistem liners adalah untuk mencegah dan meminimisasi infiltrasi leachate ke lapisan tanah dibawahnya sehingga mencegah kontaminasi ke air tanah. Umumnya sistem liners ini juga untuk mencegah larinya gas ke udara tanpa terkumpul dalam gas storage yang telah disediakan. Sebagai ilustrasi pada lapisan paling bawah suatu TPA hendaknya merupakan compacted clay liner (CCL) (tebal $60 \mathrm{~cm}$ ), diatasnya dilapisi flexible membrane liner (FML) $40 \mathrm{~mm}$, kemudian baru diletakkan pasir-kerikil (untuk pengumpulan leachate) setebal $30 \mathrm{~cm}$, dilapisi lagi dengan geotextile, kemudian dilapisi tanah setebal 60 $\mathrm{cm}$ dan baru lapisan sampah kota. Teknik dan sistem liners sangat bervariasi tergantung pada kondisi dan karakteristik tanahnya. Pada wilayah yang dibawahnya sama sekali tidak ada akuifer air tanah, maka compacted clay sudah cukup.

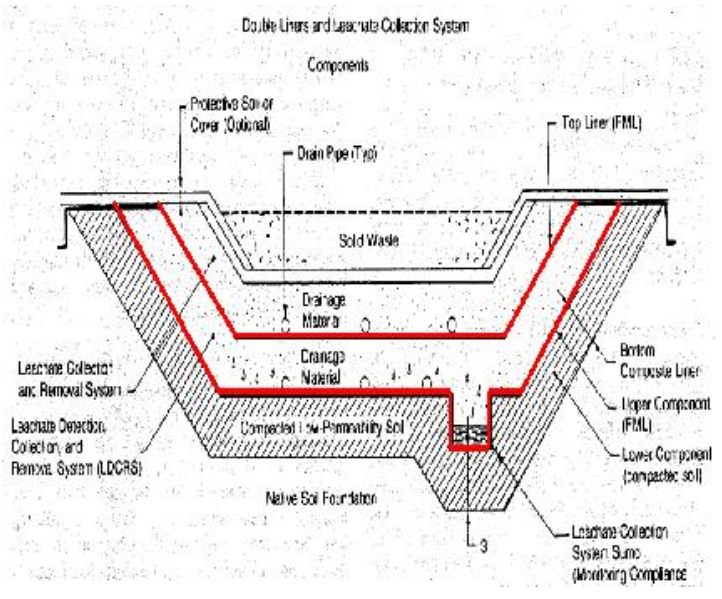

Gambar 2. Sistem liners TPA Sanitary Landfill.

Pada dasarnya tanah asli di bawah TPA mempunyai kemampuan untuk mengadsorpsi dan mendegradasi pencemar, namun adanya 
lapisan liner tambahan akan lebih menjamin hal tersebut diatas. Tanah lempung mempunyai kemampuan yang baik dalam menahan pencemar anorganik (seperti logam berat) melalui mekanisme sorpsi. Penggunaan campuran tanah yang bersifat alkalin sebagi tanah penutup akan menaikkan $\mathrm{pH}$ leachate, sehingga proses dekomposisi akan lebih cepat, terutama guna mendorong konversi karbon organik ke pembentukan gas metan disamping memungkinkan logam-logam tertentu menjadi terendapkan.

Selain sistem liners, juga perlu diperhatikan adalah kemiringan teras (slope) dan sistem perpipaan pengumpul leachate. Untuk mencegah terakumulasinya leachate di suatu tempat di dasar TPA, maka suatu seri teras yang berslope harus dibuat didasar TPA, sehingga leachate dapat dialirkan melalui pipapipa. Jaringan perpipaan pengumpul leachate merupakan bagian penting dari sistem pengelolaan leachate.

Secara umum sekali leachate terbentuk, maka opsi pengelolaannya adalah;

- Daur ulang (leachate recycling)

- Penguapan (leachate evaporation)

- Diolah dan dibuang (treat and disposal)

- Dibuang ke sistem air buangan kota

\section{KESIMPULAN}

Penanganan leachate di TPA dapat dilakukan dengan berbagai cara antara lain :

- Memanfaatkan sifat-sifat hidrolis dengan pengaturan air tanah sehingga aliran leachate tidak menuju ke arah air tanah.

- Mengisolasi TPA tersebut agar air eksternal tidak masuk dan leachate-nya tidak keluar.

- Mencari lahan yang mempunyai tanah dasar dengan kemampuan baik untuk menetralisir cemaran.

- Mengembalikan leachate (resirkulasi) ke arah timbunan sampah.

- Mengalirkan leachate menuju pengolah air buangan domestik.

- Pengolahan leachate dengan mengalirkan pada suatu artificial wetland

- Mengolah leachate dengan pengolahan sendiri, yang biasa digunakan adalah :

- Pengolahan kimia fisika, biasanya koagulasi-flokulasi-pengendapan.

- Pengolahan secara aerobik ; proses lumpur aktif, kolam stabilisasi atau kolam aerasi.

- Pengolahan secara anaerobik, biasanya kolam stabilisasi.

- Pemanfaatan sifat-sifat sorpsi seperti karbon aktif.
- Pengolahan leachate dengan mengalirkan pada suatu artificial wetland.

Di negara maju biasanya masalah leachate ini ditangani dengan diolah seperti halnya air limbah biasa. Pengelolaan leachate pada dasarnya sangat tergantung kepada karakteristiknya, sedangkan karakteristik leachate juga sangat tergantung bagaimana leachate tersebut terbentuk/ terakumulasi. Secara ideal suatu pengolahan leachate harus dilakukan uji keterolahan terlebih dahulu (treatability) dan dibuat juga skala pilotnya.

Penelitian laboratorium dan lapangan telah banyak mencatat bahwa proses resirkulasi leachate akan mempercepat stabilitas timbunan. Dari sana disimpulkan bahwa pengembalian leachate ke massa sampah akan dapat menurunkan beban organik sampai $90 \%$. Resirkulasi pada prakteknya di beberapa TPA juga dapat mengurangi bau dan lalat serta memperbanyak gasbio yang terbentuk.

\section{DAFTAR PUSTAKA}

- Damanhuri, E, (1995) Teknik Pembuangan Akhir (TPA), Diktat Kuliah, TL-ITB

- Damanhuri, T.P, (1993), Pengelolaan Lindi di TPA Sampah Dalam Kaitannya Dengan Pencegahan Pencemaran Lingkungan, Proceeding Seminar Nasional Pengelolaan Lingkungan - Tantangan Masa Depan, Jurusan Teknik Lingkungan ITB, ISBN 9798456-00-9

- De Walle, F.B., Chian, E.S, (1978) Gas Production from Solid Waste in Landfill, Journal of the Environmental Engineering Division, ASCE, v.104 p.p 415

- Eleazer, W.E., Odle, W.S., Wang, Y.S. and Barlaz, M.A. (1997). Biodegradability of municipal solid waste components in laboratory-scale landfill. Environ. Sci. Technol. 31:911-917.

- Farquhar, G.J., \& Rovers, F.A., (1973) Gas Production During Refuse Decomposition, Water, Air and Soil Pollution, 2 p 483-495

- Institute of Wastes Management Sustainable Landfill Working Group (IWMLWG) (1999).The Rational and Operation of the Flushing Bioreactor.

- Krol, A., Rudolph, V. and Swarbrick, G. (1994). Landfill : A Containment Facility or a Process Operation. Paper presented at the 2nd National Hazard \& Solid Waste Convention, Melbourne.

- Leckie, J.O, Pacey, J.G, \& Halvadakis, (1979), Landfill Management with Moisture Control, Journal Environmental Division, 105 p 337-355 
- Mc Bean, E.A, FA. Rovers \& G.J, Farquhar (1995), Solid Waste Landfill Engineering \& Design, Prentice Hall PTR, Englewood Cliffs

- Merz, R.C \& R.Stone, (1970), Special Studies of a Sanitary Landfill, U.S Department of Health, Education and Walfare, Washington DC

- Purwasasmita, M., (1989), Teknik Pengelolaan Sampah Terpadu Dengan Konsep KIS, Pusat Penelitian Teknologi ITB, Bandung

- Qasim, S.R, \& Chiang, W., (1994), Sanitary Landfill Leachate, Technomic Publication

- Tchobanoglous, G., Theisen, H., Vigil, S, (1993), Integrated Solid Waste Management, McGraw Hill Book, Co, Singapore 